\title{
Accounting and Finance Education in Nigeria: Challenges and Changes for Efficiency
}

\author{
Mansur Muhammad Bashar \\ (Bursary Department, Usmanu Danfodiyo University, Sokoto, Nigeria.)
}

\begin{abstract}
In this study, an attempt was made to reflect into the historical development of Accounting and Finance education in Nigeria. It examined the various challenges bedeviling the system and the need to refocus because it provides an opportunity to appraise existing conditions with a view to correcting the ills and improving the current situation. The study revealed that development of accounting education in Nigeria has been affected by lack of teachers and research facilities and funding among others. The study recommended among others that government should stop paying lip service to education and the system should be redesigned to make it more responsive to the needs of the Nigerian society.
\end{abstract}

Keywords: Accounting and Finance Education, Challenges, Curriculum, Teaching and Research facilities

\section{Introduction}

Knowledge explosion and information revolution of today provides an opportunity for acquiring global knowledge. This revolution however is placing serious demand for adequate investment in human capital development. This is because in a globalized world, natural resources are no longer the key to effective competition. The key is knowledge which is acquired through formal education.According to The American Accounting Association (AAA 1986) Accounting and finance education is that field of education that generates human resource capacity for the provision and application of qualitative information, primarily financial in nature, about economic entities that is intended to be useful in economic decisions. This information allows users to make reasoned choices among alternative uses of scarce resources in the conduct of business and economic activities. The need for accounting therefore arose in response to the desire to make judicious use of scarce resources, accumulate wealth and produce high quality of goods and services in a competitive economy. To perform these roles, accountants are needed both in number and in quality and this is a function of the level of accounting education available (Armstrong, 2010).

An appropriate level of accounting education must embrace the development of the character of the aspiring accountant in such a manner as to engender in him or her a strong moral code; a sense of discretion; an almost total commitment to the confidentiality of information or data established as a result of work carried out; an enquiry and analytical mind consistent with providing clients with high standards of professional services; an ability to assess data and situations and to prepare reports in such a way as to impress upon users of accounting services that their problems have been addressed in ways consistent with the highest ideals of a true professional, a sense of dress and carriage designed to develop a confidence in the competence and probity of the practitioners within the profession (Kimmel, 1995; Maher,2000;Ravenscroft \& Williams, 2003). The importance of Accounting and Finance education as a tool for the rapid socio-economic development have long been recognized by Nigerians. To justify this, reasonable efforts have long been made over the years for the advancement of the profession in the country. Prominently among such efforts is the establishment of the first indigenous professional accounting body, the Institute of Chartered Accountants of Nigeria (ICAN). It was established by an Act of parliament in 1965. ICAN was and is still responsible for the training and certification of professional accountants in Nigeria. It participates in the regulation of general accounting practice in Nigeria. In 1993, another professional accounting body was formed via a decree No. 79 of 1993. The body is called Association of National Accountants of Nigeria (ANAN). The association is responsible for ensuring the best practices in the profession and also participates in the general regulation of accounting practice in Nigeria.Despite all these efforts however, Accounting and finance education in Nigeria is faced with series of challenges ranging from poor resource allocation, inadequate human capacity, narrow curricular e.t.c. (Arnold, 2000).Nigeria over the years have witnessed incidences of financial scandals. The Unilever Plc and Cadbury Nigeria Plc are cases in point. There are certainly other instances of financial scandals both in Nigeria and elsewhere that are not publicly discussed. The collapse of these corporations arising essentially from failures in their accounting practices has far reaching implications for accounting and finance education in Nigeria as well as for the accounting professional bodies. It is an indictment of the quality of the accounting education system and hence the need to evaluate the quality and relevance of accounting education delivery in Nigeria. (Ezeani, 2012). 
In this paper, an attempt has been made to trace briefly the historical development of accounting and finance education in Nigeria. Challenges bedeviling the system are briefly identified and the changes required to ensure efficiency are discussed.

\section{Historical Development Of Accounting And Finance Education In Nigeria}

The historical development of Accounting and finance education cannot be isolated from the advent of western education in Nigeria. According to Wintoki (1997) and Coker (1990) the development of accounting in Nigeria can be traced to the time when the Companies Ordinance of 1922 was enacted. The second major development of accounting education and training in Nigeria took place in the early 1960s, when the Colleges of Arts, Science and Technology were established in Ibadan, Enugu and Zaria in 1963, (Uche 2003). The development of the accounting profession in the country has been assisted by the establishment of the department of accounting in the Nigerian Universities, Polytechnics and Colleges of Technology (Badejo, 1997; Ajayi, 1996). The Nigerian system of government accounting has its roots from the British colonialists who were confronted with accounting and reporting problems that required resolution without the assistance of Professional accounting standard-setting organizations. In those early days, the primary focus of financial accounting and reporting was determining whether cash, usually generated from tax levies to support current operating activities was collected in amounts that at- least equaled the cash paid for the purpose of generating such cash and whether laws restricting the collection and expenditure of public funds were followed by those who administered the programs (Uche 2003). After Nigeria's independence in 1960, the first indigenous professional accounting body is the Institute of Chartered Accountants of Nigeria (ICAN). It was established by an Act of parliament in 1965. ICAN was and is still responsible for the training and certification of professional accountants in Nigeria. It participates in the regulation of general accounting practice in Nigeria. In 1993, another professional accounting body was formed via a decree No. 79 of 1993. The body is called Association of National Accountants of Nigeria (ANAN). The association is responsible for ensuring the best practices in the profession and also participates in the general regulation of accounting practice in Nigeria. Onuorah and Ebimbowei (2012) are of the view that the accounting system being operated by the Nigerian public service and the overall accounting realm is being dictated by the regulatory role played by ICAN and ANAN.The accumulation of wealth and the growth of capital, the expansion of production and trade, and development created the need for financial information and control. Accounting is therefore a response to the demand of economic and financial exigencies of the society (Ibadin and Oyakhiromhe, 2010).

\section{Challenges Of Accounting And Finance Education In Nigeria}

A review of literature has revealed that accounting and finance education in Nigeria is engulfed with some challenges and threats which influence the development of the profession in any country. The following according to Iyoha (2011), are identified threats to future of accounting profession:

(a) Economic Condition: Economic conditions are a major determinant in the development of a country's accounting profession. Hence the impact of economic environment on accounting development/practice has enjoyed wide discussion in accounting literature. As economies develop, it is argued that, the social function of accounting to measure and communicate economic data becomes important.

(b) General Education: The way in which accountants are educated and the sophistication of that education are critical to the ability of the profession to develop and perform its duties and responsibilities. Hence education can be seen as the pillar for modern complex accounting system.

(c) The Profession: The strength and competence of a profession can be influenced by the profession itself. That is, the policy a profession adopts and the attitude of the society towards those policies can affect the status of the profession, the type of persons who enter it, and its credibility.

(d) The Stock market: Where a well-developed capital market does not exist, the need for informed and reliable financial statement may not be realized. But a well-developed capital market, with established stock exchanges and high degree of public shareholding, raises a critical and crucial need for reliable financial reporting and disclosure.

According to Okolie (2014), the challenges confronting the accountant in his role to the society at large in a dynamic and complex environment have been a great concern to the accounting profession. He enumerated the following among others, as the challenges facing accounting education in Nigeria; institutions, Accounting research, the teacher, funding and the curriculum. Okafor (2012) posit that, the role of the accountant is now changing from that of maintaining proper accounting processes to that of making proper financial decision making. Lack of professional skills and proper ethics in the discharge of accounting functions in numerous corporate organizations, have contributed largely to most of the recent global financial crisis. She identified the Curricular, funding, teaching and learning facilities, teaching aids and pedagogy, staffing of accounting departments and institutional influences as some of the challenges facing Accounting and finance education in 
Nigeria. Ezeani (2012) also highlighted the challenges being faced by Accounting and Finance education as lack of knowledge, curriculum development and funding.

From the forgone it is glaring that no doubt accounting and finance education is faced with a lot of challenges in Nigeria. However, the following stand out as the major challenges bedeviling Accounting and finance education in Nigeria:

- $\quad$ Funding

- Teaching and Accounting Research facilities

- Curriculum

\section{a. Funding}

One major problem plaguing the development of education generally in Nigeria is inadequate funding. Below is a record from the budget office of the federation showing budgetary allocations to the education sector compared to the overall budget for the period 2007-2016(ten years):

\begin{tabular}{|l|l|l|l|l|}
\hline SN & Year & $\begin{array}{l}\text { Total Budget } \\
\text { N'trillion }\end{array}$ & $\begin{array}{l}\text { Allocation to Education } \\
\text { N'trillion }\end{array}$ & $\begin{array}{l}\text { Percentage Allocation to Education } \\
\%\end{array}$ \\
\hline 1 & 2007 & 2.301 & 0.189 & 8.2 \\
\hline 2 & 2008 & 2.450 & 0.220 & 8.9 \\
\hline 3 & 2009 & 2.870 & 0.184 & 6.4 \\
\hline 4 & 2010 & 4.600 & 0.295 & 6.4 \\
\hline 5 & 2011 & 4.840 & 0.306 & 6.3 \\
\hline 6 & 2012 & 4.877 & 0.400 & 8.2 \\
\hline 7 & 2013 & 4.920 & 0.426 & 8.7 \\
\hline 8 & 2014 & 4.642 & 0.495 & 10.6 \\
\hline 9 & 2015 & 4.493 & 0.415 & 9.2 \\
\hline 10 & 2016 & 6.061 & 0.403 & 6.6 \\
\hline
\end{tabular}

Source: www.budgetoffice.gov.ng (2017)

The effect of inadequate funding of the educational system will no doubt lead to poor or weak physical structures at all levels. Irregular and or non-payment of teachers' salaries and poor or lack of physical developments in institutions. These ultimately is the main cause of frequent strikes and industrial disharmony by school teachers, lecturers and workers at all levels of education. Accounting as one of the various disciplines in the education system has suffered the same fate of poor funding. It is obvious that the percentage allocated to education is far less than the 26\% recommended by United Nations Educational, Scientific and Cultural Organization (UNESCO) that nations should allocate to education from their national budget. This has no doubt affected the development of education in Nigeria, and by implication, accounting education.

\section{b. Teaching and Accounting Research Facilities}

Effective understanding of accounting requires effective teaching and research facilities. Lack of adequate facilities and materials has totally rendered the teachers helpless in their bid to impart knowledge on their students. The teacher needs an enabling environment to maintain effectiveness in their teaching process. Research generates knowledge, and teaching helps people to acquire and use it. It is universally accepted that part of the obligations of the academics is to conduct research. It is equally obligatory for members of the profession to provide sound education to its members both before and after qualification, (Birnberg, 2000; Rebele, Stout \& Hassell, 1991).According to (Odiaka \& Nwachukwu, 2008), in Nigeria, there has not been indepth research into accounting principles and practices in the face of global challenges. The results of such research are expected to provide latest accounting techniques, new theoretical knowledge and the discovery of new accounting packages that will meet both local and international standard. It is hoped that if adequate fund is provided, academics and practitioners will be encouraged to research into different aspects of accounting.

\section{c. Curriculum}

The curriculum refer to the totality of lessons and academic content taught in a school or in a specific course. The curriculum for the accounting profession must produce products who have acquired a mixture of skills which include: interpersonal, communication, intellectual and other skills for public accounting. Future accountants must also possess knowledge in organizational administration, business, accounting, audit apart from general knowledge and knowledge in for public accounting. Despite this noble requirement however, the curriculum operational in Nigeria is adjudged not to be flexible enough to incorporate these new developments in accounting standards, guidelines, theories and information technology and this has affected the quality of graduates from the various higher institutions of learning. (Okolie and Amos, 2014). 


\section{Changes Required Enhancing Efficiency Of The System.}

Having carefully reviewed the progress made and challenges bedeviling the system discussed, it is imperative that some useful insights be made into the best strategies required to reverse the decline and reform the system.

1. Education should be accorded priority. Governments should invest heavily on education by funding it adequately. The UNESCO recommendation of $26 \%$ annual allocation should be met. Accounting education is very cost intensive in terms of capital and recurrent expenditures. There is need for educational institutions to generate more funds internally, institutions should retool their machinery for internally generated revenue (IGR). There should be sound networking among governments, entrepreneurs, alumni associations and other stakeholders for financial support ethically. The Parents Teachers Association (PTA) which has become an effective instrument for mobilizing funding support for primary and secondary institutions could be upgraded and adopted for similar purposes at the university level.

2. The role of teaching and accounting research should be redefined. They should be adequately motivated and should benefit from continuous training and research for success to be achieved in the new era. Their condition of service should be such that can attract and retain capable hands that can produce great minds.

3. There is need for revolutionary ideas and fresh initiatives aimed at rebuilding the system to enable it grow in line with growth and developments across the globe. Accounting education curriculum should therefore be redesigned to meet the challenges of the day. Emphasis should be on the promotion of information technology and entrepreneurship which are the main drivers of the modern world.

\section{Conclusion}

This paper discussed the development of Accounting and finance education in Nigeria. It identified inadequate funding, teaching and research facilities and the curriculum as the major areas of concern among the factors bedeviling the system. It was recommended among others that government should stop paying lip service to education and the system should be redesigned to make it more responsive to the needs of the Nigerian society.

\section{References}

[1] American Accounting Association (AAA). (1986). Committee on the Future Structure, Content, and Scope of Accounting Education, (the Bedford Report), "Future Accounting Education: Preparing for the Expanding Profession", Issues in Accounting Education, spring, pp. 168-195.

[2] Armstrong, M. B. (2010). 'Ethics and Professionalism in Accounting Education: a Sample Course', Journal of Accounting Education, vol. 11, no. 1, pp. 77-92. http://dx.doi.org/10.1016/0748-5751 (93)90019-F

[3] Kimmel, P. (1995). A Framework for Incorporating Critical Thinking into Accounting Education. Journal of Accounting Education 12(3), pp. 299-318. http://dx.doi.org/10.1016/0748-5751 (95)00012-B

[4] Maher, M.W. (2000). Management Accounting Education at the Millennium. Issues in Accounting Education, 15, (20), $335-346$. http://dx.doi.org/10.2308/iace.2000.15.2.335

[5] Ravenscroft, S. \& P.F. Williams. (2003). Considering Accounting Education Post Enron. Working paper, Iowa State University.

[6] Arnold, J. (2000) Research in Accounting and Finance: Methods and Prospects. The Nigerian Accountant, 33(2) pp.6-14.

[7] Ezeani, N.S. (2012). The Place of Globalization on Accounting Education in Nigerian Tertiary Institutions. Singaporean Journal of Business, Economics and Management Studies. Vol 1, No.4.

[8] Wintoki, M. B. (1997). Research into Accounting Education in Nigeria: Challenges and Prospects. (Ed, E. O. Adegite) Lagos, University of Lagos Press pp 45-57.

[9] Coker, F.C.O. (1990) How It All Started. The Nigerian accountant, 23(3) pp.23-24

[10] Uche, C.U. (2003).Professional Accounting Development in Nigeria: Threats from the Inside and outside. Accounting, Organizations and Society, Vol.27, pp.471-496.

[11] Badejo, A. O. (1997). Objectives and Features of Professional Education and Training: Accounting Education in Nigeria: Challenges and Prospects (Ed, E. O. Adegite) Lagos: University of Lagos Press.

[12] Ajayi, C. A. (1996). "The Role of University in the Training and Education of Accountants in Nigeria: Past, Present and Future" (Ed. E. O. Ogunjimi and S. O. Aderemi) pp 88-97.

[13] Onuorah, A and Ebimbowei, A. (2012). Accountability and Public sector financial management in Nigeria. Arabian Journal of Business and Management Review. Vol. 1, No 6.

[14] Ibadin LA and Oyakhiromhe AB (2010). The Development of Accounting in Nigeria (With Special Emphasis on the Key Role Players in Education, Training and Practice). Knowledge Review Journal. Vol 20, No.1

[15] Iyoha, F. O. (2011). State Agencies, Industry Regulations and the Quality of Accounting Practice in Nigeria. (Ph.D. Thesis) Covenant University, Ota, Ogun State, Nigeria. (Unpublished).

[16] Okolie, O. R., \& Amos, A. (2014). The challenges of accounting education: the Nigerian experience. Accounting and Finance Research, 3(2), 129-137.

[17] Ezeani, N.S. (2012). Repositioning the Accounting Profession through professional Ethics. International Journal of the Common Wealth Research and Capacity Education Initiative (IJCWRCEI) 3(3), 70-88.

[18] Birnberg, J.G. (2000). The Role of Behavioral Research in Management Accounting in the 21st Century. Issues in Accounting Education, 15, (4), 713-728. http://dx.doi.org/10.2308/iace.2000.15.4.713

[19] Rebele, J. E., D. E. Stout, \& J. M. Hassell. (1991). A Review of Empirical Research in Accounting Education: 1985-91. Journal of Accounting Education 9, 167-231. http://dx.doi.org/10.1016/0748-5751(91)90003-A

[20] Odiaka, L. D. \& Nwachukwu, A. J. (2008) Institutional Pressures on University Accounting Education, Contemporary Accounting Research, p 141. 